\title{
A New Alkene Glycoside from the Leaves of Sasa quelpaertensis Nakai
}

\author{
Nasim Sultana ${ }^{\dagger}$ and Nam Ho Lee ${ }^{*}$ \\ Department of Chemistry, Cheju National University, Jeju 690-756, Korea.*E-mail: namho@cheju.ac.kr \\ ${ }^{\dagger}$ Analytical Research Division, Bangladesh Council of Scientific \& Industrial Research (BCSIR) Laboratories Dhaka, \\ Dr. Qudrat-I-Khuda Road, Dhanmondi, Dhaka-1205, Bangladesh \\ Received January 30, 2010, Accepted February 16, 2010
}

Key Words: Sasa quelpaertensis, Gramineae, Alkene glycoside, Free radical scavenging activity

Sasa quelpaertensis Nakai (Korean name, Jejujoritdae), belonging to a family Gramineae, is an edible bamboo grass endemic to Jeju Island, Korea. S. quelpaertensis is one of the most abundant plant species among the plant varieties in the area of Halla Mountain located in Jeju. ${ }^{1}$ Its dried leaves are being used as a tea for the treatment of diabetes and gastritis in the local community. Our previous chemical studies on the leaves of this plant resulted in the isolation of anti-tyrosinase compounds 1-5. In continuation of our efforts to explore biologically active compounds from plants in Jeju, ${ }^{3}$ we further investigated on the leaves of this bamboo grass of which the ethyl acetate extract displayed free radical scavenging activities.

Production of free radicals in a living organism is primarily initiated from superoxide, which is generated as by-products in normal cellular metabolism. Free radicals are extremely reactive chemical species and can make a random attack to cellular lipids, proteins and DNA to cause their deterioration. It has been reported that a series of human illness such as inflammation, cardiovascular disease, rheumatoid arthritis and premature body aging can be linked to the damaging action of reactive free radicals. ${ }^{4}$ Therefore, it becomes of significance to develop novel free radical scavenging agents potentially applicable in medicinal or cosmetic preparations.

In this study, besides the previously isolated compounds 1-5, nine compounds 6-15 were additionally isolated from the leaves of $S$. quelpaertensis. Among these, the alkene glycoside $\mathbf{6}$ was identified as a new compound. In addition, the rest of the compounds 7-15 were also isolated for the first time from this plant. Herein, we describe the structure characterization and the evaluation of radical scavenging activities for the compounds isolated from $S$. quelpaertensis.

The plant extract was prepared using $70 \%$ ethanol from the leaves of $S$. quelpaertensis at room temperature. The extract was suspended in water and partitioned successively into $n$-hexane, ethyl acetate (EtOAc), and $n$-butanol. As DPPH radical scavenging activities were examined for the solvent fractions, EtOAc fraction showed relatively strong activity (22\% inhibition at $50 \mu \mathrm{g} / \mathrm{mL}$ ) compared to the other fractions. In order to identify the active constituents, EtOAc fraction was subjected to purification by various column chromatography to afford compounds 6-15 including a new compound 6 (Figure 1).

The compound $\mathbf{6}$ was obtained as a colorless syrup. In the<smiles>COc1cc(C(CCOC(=O)/C=C/c2ccc(O)cc2)OC(C)(C)O)cc(OC)c1O</smiles>

1
2<smiles>[R]c1cc(/C=C/C(=O)NCCc2c[nH]c3ccc(O)cc23)ccc1O</smiles>

$3, \mathrm{R}=\mathrm{H}$ 4, $\mathrm{R}=\mathrm{OCH}_{3}$<smiles>O=C(O)/C=C/c1ccc(O)cc1</smiles>

5

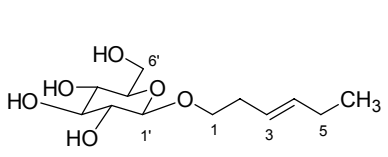

6

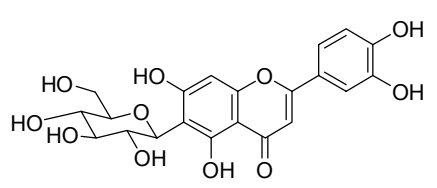

13<smiles>O=C(O)c1ccc(O)cc1</smiles>

7<smiles>COc1cc(C(=O)CCO)cc(OC)c1O</smiles>

8

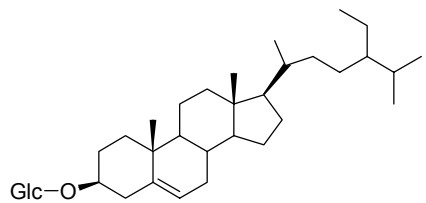

14<smiles>COc1cc(O)c2c(=O)cc(CO)oc2c1</smiles>

9
10, $\mathrm{R}_{1}=\mathrm{H}, \quad \mathrm{R}_{2}=\mathrm{H}$

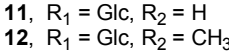<smiles>CC1=C[C@H](O)CC(C)(C)C1/C=C/C(C)=C/C=C/C(C)=C/C=C/C=C(C)/C=C/C=C(C)/C=C/C1=C(C)C[C@H](O)CC1(C)C</smiles>

Figure 1. Structures of the compounds isolated from S. quelpaertensis. 
Table 1. NMR (400 MHz) spectroscopic data ( $\delta$ in ppm, $\mathrm{CDCl}_{3}$ ) for compound 1

\begin{tabular}{clrl}
\hline Position & $\delta_{\mathrm{H}}($ int, mult, $J$ in Hz) & \multicolumn{1}{c}{$\delta_{\mathrm{C}}$} & \multicolumn{1}{c}{ HMBC } \\
\hline 1 & $3.84(2 \mathrm{H}, \mathrm{m})$ & 69.5 & \\
2 & $2.36(2 \mathrm{H}, \mathrm{dt}, 7.3,6.8)$ & 27.9 & $\mathrm{C}-1, \mathrm{C}-3$ \\
3 & $5.34(1 \mathrm{H}, \mathrm{dt}, 17.1,7.3)$ & 124.3 & $\mathrm{C}-2, \mathrm{C}-5, \mathrm{C}-1$ \\
4 & $5.45(1 \mathrm{H}, \mathrm{dt}, 17.1,7.3)$ & 134.3 & $\mathrm{C}-2, \mathrm{C}-5$ \\
5 & $2.03(2 \mathrm{H}, \mathrm{dq}, 7.3,6.8)$ & 20.8 & $\mathrm{C}-4, \mathrm{C}-6$ \\
6 & $0.94(3 \mathrm{H}, \mathrm{t}, 6.8)$ & 14.4 & $\mathrm{C}-4, \mathrm{C}-5$ \\
1 & $4.32(1 \mathrm{H}, \mathrm{d}, 8.0)$ & 102.9 & $\mathrm{C}-1$ \\
$2^{\prime}$ & $3.38(1 \mathrm{H}, \mathrm{dd}, 8.0,8.8)$ & 73.5 & \\
$3^{\prime}$ & $3.28(1 \mathrm{H}, \mathrm{t}, 8.8)$ & 76.5 & \\
4 & $3.60(1 \mathrm{H}, \mathrm{t}, 8.8)$ & 69.9 & \\
$5^{\prime}$ & $3.53(1 \mathrm{H}, \mathrm{m})$ & 75.7 & \\
6 & $3.84(1 \mathrm{H}, \mathrm{brs})$ & 61.5 & \\
& $3.58(1 \mathrm{H}, \mathrm{brd}, 6.8)$ & & \\
\hline
\end{tabular}

positive HRFAB-MS, it showed an $[\mathrm{M}+\mathrm{Na}]^{+}$ion peak at $\mathrm{m} / \mathrm{z}$ 285.1307 and $[\mathrm{M}+\mathrm{H}]^{+}$ion peak at $m / z 263.1477$ accounting for molecular formula $\mathrm{C}_{12} \mathrm{H}_{22} \mathrm{O}_{6}$. Its IR spectrum indicated the presence of hydroxy groups $\left(3350 \mathrm{~cm}^{-1}\right)$. Examination of ${ }^{1} \mathrm{H}$ and ${ }^{13} \mathrm{C}$ NMR spectrum (Table 1 ) showed the presence of a sugar moiety, and large ${ }^{1} \mathrm{H}-{ }^{1} \mathrm{H}$ coupling constant of anomeric proton signal at $\delta 4.32(\mathrm{~d}, J=8.0 \mathrm{~Hz})$ indicated that the sugar unit was present in the $\beta$-configuration. It showed the presence of a methyl group signal at $\delta 0.94(3 \mathrm{H}, \mathrm{t}, J=6.8 \mathrm{~Hz})$, two olefinic methine signals at $\delta 5.45(1 \mathrm{H}, \mathrm{dt}, J=17.1,7.3 \mathrm{~Hz})$ and 5.34 $(1 \mathrm{H}, \mathrm{dt}, J=17.1,7.3 \mathrm{~Hz})$, two methylene signals at $\delta 2.36(2 \mathrm{H}$, $\mathrm{dt}, J=7.3,6.8 \mathrm{~Hz})$ and $2.03(2 \mathrm{H}, \mathrm{dq}, J=7.3,6.8 \mathrm{~Hz})$, an oxymethylene signal at $\delta 3.84(2 \mathrm{H}, \mathrm{m})$. These data indicated the presence of $\mathrm{CH}_{3}-\mathrm{CH}_{2}-\mathrm{CH}=\mathrm{CH}-\mathrm{CH}_{2}-\mathrm{CH}_{2}-\mathrm{O}$ - spin system in $\mathbf{6}$. Besides the presence of hexose sugar moiety, the ${ }^{13} \mathrm{C}$ NMR spectrum (Table 1) also revealed peaks for six carbons in the aglycone moiety such as a methyl $(\delta 14.4)$, three methylenes $(\delta 20.8,27.9$ and 69.5$)$ and two olefinic methines $(\delta 124.3$ and 134.3). The ${ }^{1} \mathrm{H}$ and ${ }^{13} \mathrm{C}$ NMR spectral data were very similar with published data ${ }^{5}$ except trans olefinic methine proton-proton coupling constant.

The structure 6 was further supported by ${ }^{1} \mathrm{H}-{ }^{1} \mathrm{H}$ COSY and the ${ }^{1} \mathrm{H}-{ }^{13} \mathrm{C} \mathrm{HMQC}$ experiments. The connection of sugar residue and 3-hexenyl group was unambiguously determined by the HMBC experiment (Table 1). In the HMBC spectrum, the anomeric proton $\left(\delta 4.32, \mathrm{H}_{-1}{ }^{\prime}\right)$ showed ${ }^{3} J$ correlation with oxygenbearing methylene carbon $(\delta 69.5, \mathrm{C}-1)$, which confirmed the attachment of the sugar unit at $\mathrm{C}-1$. On the basis of these data compound 6 was identified as a new compound, $(E)$-3-hexenyl- $\beta$-glucopyranoside.

In this study, the other known compounds were also identified by spectroscopic means including 1D and 2D NMR techniques, as well as by comparison of the data with those in the literature; 4-hydroxybenzoic acid (7), ${ }^{6} 3$-hydroxy-1-(4-hydroxy 3,5-dimethoxyphenyl)-1-propanone (8), ${ }^{7}$ saikochromone A(9), ${ }^{8}$ tricin (10), ${ }^{9}$ tricin-7- $O$-glycoside (11), ${ }^{10}$ tricitin-3', 4',5'-tri- $O$ methyl-7-O- $\beta$-glucopyranoside (12), ${ }^{10}$ isoorientin $(\mathbf{1 3}),{ }^{11}$ daucosterol (14) $)^{12}$ and lutein (15). ${ }^{13}$

The compounds (1-15) isolated from $S$. quelpaertensis were tested for their antioxidative activities using DPPH free radical scavenge method. ${ }^{14}$ The radical scavenging activities can be estimated by a loss of DPPH absorbance at $525 \mathrm{~nm}$. The activities of the isolated compounds were measured at different concentrations $(2 \sim 100 \mu \mathrm{g} / \mathrm{mL})$, and expressed as $\mathrm{IC}_{50}$ (the concentration needed to reduce $50 \%$ of DPPH). Ascorbic acid was used as a positive control showing $\mathrm{IC}_{50}$ value of $5.2 \mu \mathrm{g} / \mathrm{mL}$. As a result of activity test, serotonin derivatives $\mathbf{3}$ and $\mathbf{4}$ showed significant free radical scavenging activities with $\mathrm{IC}_{50}$ values of $8.0 \mu \mathrm{g} / \mathrm{mL}$ and $33.3 \mu \mathrm{g} / \mathrm{mL}$ respectively. AC-glycoflavonoid, isoorientin (13), also showed strong activity with $\mathrm{IC}_{50}$ value of $26.8 \mu \mathrm{g} / \mathrm{mL}$. However, the other compounds were weakly active or inactive.

\section{Experimental Section}

Reagents and equipments. Analytical grade solvents were used without further purification. UV spectra were obtained using a Biochrom Libra S22 UV-visible spectrophotometer. The IR data were recorded from sample dissolved in chloroform using a Shimadzu FT-IR 8400 S spectrometer. ${ }^{1} \mathrm{H}(400 \mathrm{MHz})$ and ${ }^{13} \mathrm{C}(100.60 \mathrm{MHz})$ NMR spectra were recorded on a JEOL JNM-LA 400 instrument, with chemical shift data in ppm relative to the used residual solvents. 2D NMR spectra were recorded on the same instrument using field gradient FG2 (inverse) probe. FABMS were obtained with $m$-nitrobenzyl alcohol matrix on JEOL JMS-700 spectrometer. Optical rotations were determined on a Jasco P-1030 automatic digital polarimeter. Vacuum liquid chromatography (VLC) and column chromatography (CC) were performed using Merck silica gel $60 \mathrm{H}$ (15 $\mu \mathrm{m})$ and silica gel $(0.063 \sim 0.2 \mathrm{~mm})$ respectively. Thin layer chromatography (TLC), Silica gel $60 \mathrm{~F}_{254}$ coated on aluminium plates, was supplied by Merck. Sephadex LH-20 (25 $100 \mu \mathrm{m})$ for gel filtration chromatography (GFC) was obtained from Fluka. Ascorbic acid and 2,2-diphenyl-1-picrylhydrazyl (DPPH) were purchased from Aldrich Chem. Co.

Plant material. The leaves of S. quelpaertensis (Korean name, Jejujoritdae) were collected in Halla Mountain, Jeju Island, Korea in February 2007. A voucher specimen (J-010) was prepared and deposited at the laboratory of natural product chemistry, Department of Chemistry, Cheju National University.

Extraction and isolation. The dried leaves of $S$. quelpaertensis $(650 \mathrm{~g})$ was cut into small pieces and extracted with $80 \%$ ethanol by stirring with magnetic stirrer at room temperature for three days. The residue in the extract was removed by filtration, and the filtrate was concentrated to a gummy residue in a rotary evaporator under vacuum at a maximum temperature of $40{ }^{\circ} \mathrm{C}$. The ethanol extract $(50 \mathrm{~g})$ was partitioned between water and $n$-hexane and the aqueous part was further portioned with ethyl acetate (EtOAc) and $n$-butanol, successively.

The EtOAc-soluble fraction $(5.0 \mathrm{~g})$ was subjected to VLC (vacuum liquid chromatography) over silica gel, eluting with $n$-hexane-EtOAc $(0 \sim 100 \%)$ and then EtOAc-MeOH $(0 \sim 50 \%)$ to afford 26 factions (200 mL each). The VLC fractions (227.6 $\mathrm{mg}$ ) eluted from $40 \sim 45 \%$ EtOAc in $n$-hexane were applied to Sephadex LH-20 column chromatography using $\mathrm{CHCl}_{3}$ (300 $\mathrm{mL}$ ) followed by $\mathrm{CHCl}_{3}-\mathrm{MeOH}(95: 5,400 \mathrm{~mL}, 20$ fractions, $20 \mathrm{~mL}$ each) to yield compound $\mathbf{1 5}(100 \mathrm{mg})$. The VLC fraction $(127.3 \mathrm{mg})$ obtained with $50 \%$ EtOAc in $n$-hexane was sub- 
sequently subjected to $\mathrm{GFC}$, eluted with $\mathrm{CHCl}_{3}$ and then $\mathrm{CHCl}_{3-}$ $\mathrm{MeOH}$ mixtures and then further fractionated by silica gel column chromatography (CC) using $\mathrm{CHCl}_{3}$ and $\mathrm{CHCl}_{3}-\mathrm{MeOH}$ $(95: 5 \mathrm{v} / \mathrm{v})$ yielded three compounds, $15(50 \mathrm{mg}), 9(6.4 \mathrm{mg})$ and $7(7.1 \mathrm{mg})$. The VLC fractions obtained from $55 \sim 60 \%$ EtOAc in $n$-hexane were combined $(185.9 \mathrm{mg})$ and similarly fractionated by gel filtration chromatography (GFC) and finally by $\mathrm{CC}$ using $\mathrm{CHCl}_{3}-\mathrm{MeOH}(95: 5, \mathrm{v} / \mathrm{v})$ to give compounds $\mathbf{1 0}$ $(5.7 \mathrm{mg})$. The VLC fractions from $80 \sim 100 \%$ EtOAc in $n$-hexane were combined $(471.8 \mathrm{mg})$ and applied to gel filtration to give $8(8.5 \mathrm{mg})$. The VLC fraction eluted with $2 \sim 7 \% \mathrm{MeOH}$ in EtOAc were combined $(1.10 \mathrm{~g})$ and subsequently subjected to GFC, eluted with $\mathrm{CHCl}_{3}-\mathrm{MeOH}(95: 5, \mathrm{v} / \mathrm{v})$ and finally silica gel $\mathrm{CC}$ using $\mathrm{CHCl}_{3}-\mathrm{MeOH}(90: 10 \mathrm{v} / \mathrm{v})$ to yield two compounds, $14(13.5 \mathrm{mg})$ and $\mathbf{6}(20.6 \mathrm{mg})$. The VLC fractions from $15 \%$ $\mathrm{MeOH}$ in EtOAc were combined $(610 \mathrm{mg})$ and treated to GFC, eluted with $\mathrm{CHCl}_{3}-\mathrm{MeOH}(90: 10, \mathrm{v} / \mathrm{v})$ and then $\mathrm{CC}$ using same solvent system to yield two flavonoids, $11(12.1 \mathrm{mg})$ and $\mathbf{1 2}$ (8.4 mg). Finally, the VLC fractions (651 mg) eluted with 30 $50 \% \mathrm{MeOH}$ in EtOAc were treated to GFC with $\mathrm{CHCl}_{3}-\mathrm{MeOH}$ $(70: 30, v / v)$ and then $\mathrm{CC}$ using the same solvent system to yield isoorientin $(13,32.4 \mathrm{mg})$.

(E)-3-Hexenyl $\beta$-glucopyranoside (6). Colorless syrup, $[\alpha]_{\mathrm{D}}$ $-33.8^{\circ}\left(c 0.23, \mathrm{CHCl}_{3}\right)$ at $26.1{ }^{\circ} \mathrm{C}$; IR $v_{\max } 3350,1620(\mathrm{C}=\mathrm{C})$; ${ }^{1} \mathrm{H}$ and ${ }^{13} \mathrm{C}$ NMR (400 MHz, $\mathrm{CDCl}_{3}$ ), see Table 1; HRFABMS, $m / z 285.1307$ ([M+Na $]^{+}$, Calcd for $\left.\mathrm{C}_{12} \mathrm{H}_{22} \mathrm{O}_{6} \mathrm{Na}, 285.1314\right)$.

Acknowledgments. This research work was supported by grant from the Korean Ministry of Knowledge and Economy, through Regional Industry Common Technology Development Project.

\section{References}

1. Lee, Y. N.; Lee, K. S.; Shin, Y. H. Wild Plants of Jeju Island; Yeomiji Botanical Garden: Jeju, Korea, 2001; pp 1-669.

2. Sultana, N.; Lee, N. H. Bull. Korean Chem. Soc. 2009, $30,1729$.

3. Kim, J. M.; Ko, R. K.; Jung, D. S.; Kim, S. S.; Lee, N. H. Phytotherapy Res. 2010, 24, 70.

4. Denisov, E. T.; Afanas'ev, I. B. Oxidation and Antioxidants in Organic Chemistry and Biology; Taylor \& Francis: New York, 2005; pp 905-950.

5. Mizutani, K.; Yuda, M.; Tanaka, O.; Saruwatari, Y-I.; Fuwa, T.; Jia, M-R.; Ling, Y-K.; Pu, X-F. Chem. Pharm. Bull. 1988, 36, 2689.

6. Aldrich Library of ${ }^{13} \mathrm{C}$ and ${ }^{1} \mathrm{H}$ FT NMR Spectra, 1992, 2, 1080A

7. Nakasone, Y.; Takara, K.; Kouji, W.; Tanaka, J.; Yogi, S.; Nakatani, N. Biosci. Biotech. Biochem. 1996, 60, 171.

8. Kobayashi, M.; Tawara, T.; Tsuchida, T.; Mitsuhashi, H. Chem. Pharm. Bull. 1990, 38, 3169.

9. Watanabe, M. J. Agric. Food Chem. 1999, 47, 4500.

10. Marin, P. D.; Grayer, R. J.; Grujic-Jovanovic, S.; Kite, G. C.; Vitch, N. C. Phytochemistry 2004, 65, 1247.

11. Kumarasamy, Y.; Byres, M.; Cox, P. J.; Delazar, A.; Jaspars, M.; Nahar, L.; Shoeb, M.; Sarker, S. D. Chem. Nat. Compd. 2004, 40, 122.

12. Sultana, N.; Afolayan, A. J. Nat. Prod. Res. 2007, 21, 889.

13. Deli, J.; Molnar, P.; Matus, Z.; Toth, G.; Steck, A.; Niggli, U. A.; Pfander, H. Helv. Chim. Acta 1998, 81, 1815.

14. Blois, M. S. Nature 1958, 29, 1199. 